The $2{ }^{\text {nd }}$ Conf. of SSFOP "Future of Ornamental Plants in Egypt and Arab World", Cairo, Egypt, 21/2/2016

Scientific J. Flowers \& Ornamental Plants

www.ssfop.com/journal

ISSN: 2356-7864

\title{
FLOWER QUALITY CHARACTERS RESPONSE OF GRAFTED AND NON-GRAFTED CAPE JASMINE (GARDENIA JASMINOIDES ELLIS) TO FOLIAR IRON SPRAY AND PACLOBUTRAZOL TREATMENTS
}

\author{
Z.K. Salih ${ }^{*}$ A.F. Al-Maathedi ${ }^{*}$ and M.D. Al-Sawaf** \\ * Hort. \& Landscape Dept., Agric. Coll., Tikrit Univ., Iraq. \\ ** Hort. \& Landscape Dept., Agric. Coll., Mosul Univ., Iraq.
}

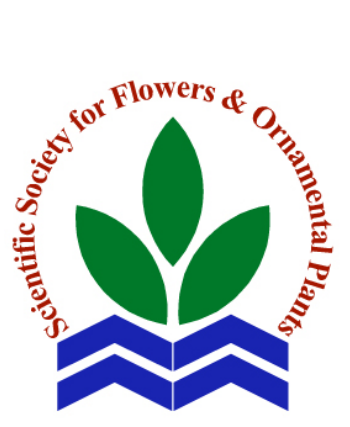

Scientific J. Flowers \& Design was used.

Ornamental Plants, 3(1):31-35 (2016).

Received:

14/1/2016

Revised by:

Prof. Dr. F.A. Al-Mana,

King Saud Univ., KSA.

Prof. Dr. A.M. Hosni, Ain

Shams Univ., Egypt. content $\left(0.68 \mu \mathrm{g} \cdot \mathrm{g}^{-1}\right)$.

ABSTRACT: Two pot experiments of grafted cape jasmine (Gardenia jasminoides on $G$. thunbergia rootstock) and non-grafted cape jasmine were carried out in lath house, Horticulture Dept., Agriculture College, Tikrit University at the agricultural season of 2013. The effect of foliar iron spray and paclobutrazol treatments on flower quality characters of these plants was investigated. Foliar iron spray $\left(\mathrm{Fe}_{2} \mathrm{SO}_{4} 6 \%\right)$ at the rate of $1 \mathrm{ml} . \mathrm{L}^{-1}$ was applied every 15 and 30 days. The paclobutrazol treatment was added as drench application on three levels $(0,10$ and 20 mg. $\left.\mathrm{L}^{-1}\right)$. Factorial experiment within Randomized Complete Block

The results showed that superior iron spraying treatment affected the flower number, weight and diameter. Foliar spray every 30 days gave the highest flower number (8.68) of grafted plant and (0.88) of non-grafted plant. Adding paclobutrazol at the level of $10 \mathrm{mg} . \mathrm{L}^{-1}$ resulted insignificant increase in flower weight of non-grafted plant (3.079). The interaction treatment between foliar iron spray every 30 days and pacloburazol level $\left(20 \mathrm{mg} \cdot \mathrm{L}^{-1}\right)$ gave the highest volatile oil

Key words: Gardenia jasminoides, grafted cape jasmine, foliar iron spray, paclobutrazol, flower quality characters.

\section{INTRODUCTION}

Gardenia jasminoides Ellis, cape jasmine gardenia (family: Rubiaceae) belongs to the acid-loving plants group. The iron chlorosis is not precisely clear and there are many reasons for this phenomena, it may cause by soil $\mathrm{pH}$, where the yellowing occurs generally in the high $\mathrm{pH}$ soil (more than 7) because it contains calcium carbonate $\mathrm{CaCO}_{3}$, which is works to raise the $\mathrm{pH}$ soil and exhibit the problem of iron absorption at $\mathrm{pH} 6.5$ up making the problem more than in the gardens is the remnants of building materials, the other reasons of iron chlorosis are, decrease of nutrients in the soil, damage of plant roots and the nature of their growth and spread (Koenig and Juhuns, 2010). The most important way to treat this phenomenon is the use of foliar iron spray whereas when added iron to soil it is useless because of the high $\mathrm{pH}$ than 7 causes oxidation of ferrous $\mathrm{Fe}^{+2}$ to ferric $\mathrm{Fe}^{+3}$ which is difficult in absorption by the plant that leads to low flowering quality (Tisdale et al., 1997). The rootstock $G$. thunbergia is used to be grafted by $G$. jasminoides to overcome some of the gardenia production problems. This rootstock has the possibility of iron absorption at low temperatures so it does not make the plants suffer when grafted on it to some extent (Al-Atrakchii and Saleh, 2008). Growth retardants are used commercially to production of pot plants since they work to retard vegetative growth without damaging 


\section{Z.K. Salih et al.}

as a phenotypic plant get a small plant size, to improve the quality of flowers and prevent undesirable elongation in the stems of some flowering plants (PGRSA, 2007). Kamoutsis and Sereli (1999) used several concentrations of paclobutrazol (0, 0.5, 1 and $2 \mathrm{mg} / \mathrm{pot}$ ) on gardenia seedlings, and showed that the treatment of paclobutrazol caused a significant decrease in the area of the plant and flowering buds rate decreased significantly with increasing the concentration of paclobutrazol. Therefore, the present study aims to determine the effect of the foliar iron spray and paclobutrazol on the flower quality specifications of cape jasmine gardenia both grafted and non-grafted.

\section{MATERIALS AND METHODS}

This study carried out in the lath house of Department of Horticulture and Landscaping, College of Agriculture, Tikrit University, during the 2013 season. The first two trials were conducted on cape jasmine, Gardenia jasminoides 'Radicans' grafted on Gardenia thunbergia 15 months old rootstock and the second on 11 months old Gardenia jasminoides 'Radicans' nongrafted. The plants were grown in plastic pots $(20 \times 20 \mathrm{~cm})$. The two experiments were designed as a factorial experiment within a Randomized Complete Block Design which consisted of 9 treatments are the interaction between spraying iron levels and the addition of paclobutrazol at a rate of four pots experimental unit. Iron fertilizer containing ferrous sulfate concentration of $6 \%$, at the rate of $1 \mathrm{ml}^{-L^{-1}}$ was used as foliar iron spray on the plant in three monthly additions (control (without spray), spraying every 15 days and spraying every 30 days). Paclobutrazol was added to the potted plant with water, drench applications of three concentrations $\left(0,10,20 \mathrm{mg} . \mathrm{L}^{-1}\right)$ at the rate of $100 \mathrm{ml} /$ pot. The paclobutrazol treatment was added after 10 days from the beginning of the experiment and added second after a month of the date of the first one. The irrigation plant stopped 48 hours to prevent paclobutrazol washing with drainage water and also to ensure the maximum rate of paclobutrazol absorption were taken. Flower bloomed occurred in April and the following measurements were taken (number of flowers, flower weight and diameter, flowering period). The amount of essential oil, essential oil density and refractive index of grafted gardenia were determined. The essential oil was extracted by organic solvents (Pensuk et al., 2007). The weight of extracted oil was divided on the weight of the sample to extract the amount of essential oil ( $\mu \mathrm{g} . \mathrm{g}^{-1}$ fresh weight of flowers). The essential oil density was measured by divided the weight (mg) on volume (100 $\mu \mathrm{L}$ ). The refractive index was measured by using Abbe Refract meter at $20^{\circ} \mathrm{C}$ temperature. Data were analyzed statistically using the statistical program SAS, and compared averages between treatments and their interaction using Duncan's Multiple Range Test, at the level of 5\% probability.

\section{RESULTS AND DISCUSSION}

Table (1) shows that the foliar iron spray caused a significant effect on whole flower characters in the grafted gardenia experiment. Foliar iron treatment every 30 days to grafted gardenia gave the highest number of flowers (8.68), highest flower weight $(6.71 \mathrm{~g})$, flower diameter $(7.61 \mathrm{~cm})$ and flowering period (7.31 days) and gave also the largest amount of essential oil, highest density and refractive index (0.64 $\mu \mathrm{g.g}{ }^{-1}, \quad 0.91 \mathrm{mg} .100 \mu \mathrm{L}^{-1}$ and 1.51, respectively). Paclobutrazol treatment with 10, 20 mg. $\mathrm{L}^{-1}$ caused significant reduction in the grafted experiment for number of flower 7.76 and 7.55 flower per plant respectively, while the treatment of $20 \mathrm{mg} . \mathrm{L}^{-1}$ increased in flower weight, diameter and flowering period (6.20 g, $7.14 \mathrm{~cm}$ and 6.73 days, respectively) and gave the largest amount of essential oil, essential oil density $\left(0.55 \mu \mathrm{g} \cdot \mathrm{g}^{-1}\right.$, 0.88 mg.100 $\mu \mathrm{L}^{-1}$ ) respectively. The interaction treatment between foliar iron every 30 day and 0 mg. $\mathrm{L}^{-1}$ drench application paclobutrazol gave the highest number of flowers (8.95) and the highest flower diameter $(7.88 \mathrm{~cm})$. 
Table 1. Effect of foliar iron spray and paclobutrazol on flower quality characters of grafted cape jasmine Gardenia jasminoides Ellis.

\begin{tabular}{|c|c|c|c|c|c|c|c|}
\hline Treatments** & $\begin{array}{l}\text { Number of } \\
\text { flowers }\end{array}$ & $\begin{array}{c}\text { Flower } \\
\text { weight } \\
\text { (g) }\end{array}$ & $\begin{array}{c}\text { Flower } \\
\text { diameter } \\
(\mathbf{c m})\end{array}$ & $\begin{array}{c}\text { Flowering } \\
\text { period } \\
\text { (days) }\end{array}$ & $\begin{array}{c}\text { Amount of } \\
\text { essential oil } \\
\left(\mu g^{-1} g^{-1}\right)\end{array}$ & $\begin{array}{c}\text { Essential oil } \\
\text { density } \\
\left(\mathrm{mg.100} \mu \mathrm{L}^{-1}\right)\end{array}$ & $\begin{array}{c}\text { Refractive } \\
\text { index }\end{array}$ \\
\hline Non foliar spray & $6.83 \mathrm{c}^{*}$ & $5.41 \mathrm{c}$ & $6.27 \mathrm{c}$ & $5.66 \mathrm{c}$ & $0.43 \mathrm{c}$ & $0.84 \mathrm{c}$ & $1.48 \mathrm{c}$ \\
\hline Ir 15 days & $7.69 \mathrm{~b}$ & $5.83 \mathrm{~b}$ & $6.70 \mathrm{~b}$ & $6.64 \mathrm{~b}$ & $0.51 \mathrm{~b}$ & $0.86 \mathrm{~b}$ & $1.50 \mathrm{~b}$ \\
\hline Ir 30 days & $8.68 \mathrm{a}$ & $6.71 \mathrm{a}$ & $7.61 \mathrm{a}$ & $7.31 \mathrm{a}$ & $0.64 \mathrm{a}$ & $0.91 \mathrm{a}$ & $1.51 \mathrm{a}$ \\
\hline P 0 & $7.88 \mathrm{a}$ & $5.88 \mathrm{c}$ & $6.61 \mathrm{c}$ & $6.27 \mathrm{~b}$ & $0.52 \mathrm{~b}$ & $0.86 \mathrm{C}$ & $1.49 \mathrm{a}$ \\
\hline P 10 & $7.76 \mathrm{~b}$ & $5.97 \mathrm{~b}$ & $6.80 \mathrm{~b}$ & $6.61 \mathrm{a}$ & $0.51 \mathrm{c}$ & $0.87 \mathrm{~b}$ & $1.49 \mathrm{a}$ \\
\hline P 20 & $7.55 \mathrm{c}$ & $6.20 \mathrm{a}$ & $7.14 \mathrm{a}$ & $6.73 \mathrm{a}$ & $0.55 \mathrm{a}$ & $0.88 \mathrm{a}$ & $1.49 \mathrm{a}$ \\
\hline $\begin{array}{l}\text { P 0 } \\
\end{array}$ & $6.70 \mathrm{~h}$ & $5.12 \mathrm{i}$ & $6.53 \mathrm{f}$ & $5.17 \mathrm{e}$ & $0.43 \mathrm{f}$ & $0.83 \mathrm{~g}$ & $1.48 \mathrm{~d}$ \\
\hline Non foliar P 10 & $6.91 \mathrm{~g}$ & $5.45 \mathrm{~h}$ & $6.25 \mathrm{~h}$ & $5.83 \mathrm{~d}$ & $0.43 \mathrm{f}$ & $0.84 \mathrm{f}$ & $1.48 \mathrm{~d}$ \\
\hline P 20 & $6.87 \mathrm{~g}$ & $5.66 \mathrm{~g}$ & $6.03 \mathrm{i}$ & $5.99 \mathrm{~d}$ & $0.44 \mathrm{f}$ & $0.84 \mathrm{f}$ & $1.48 \mathrm{~d}$ \\
\hline P 0 & $8.00 \mathrm{~d}$ & $5.82 \mathrm{f}$ & $7.00 \mathrm{~d}$ & $6.38 \mathrm{c}$ & $0.50 \mathrm{e}$ & $0.85 \mathrm{e}$ & $1.49 \mathrm{c}$ \\
\hline Ir 15 days $P 10$ & $7.66 \mathrm{e}$ & 5.87 e & $6.68 \mathrm{e}$ & $6.72 \mathrm{~b}$ & $0.50 \mathrm{e}$ & $0.87 \mathrm{~d}$ & $1.50 \mathrm{~b}$ \\
\hline P 20 & $7.41 \mathrm{f}$ & $6.11 \mathrm{~d}$ & $6.47 \mathrm{~g}$ & $6.83 \mathrm{~b}$ & $0.54 \mathrm{~d}$ & $0.87 \mathrm{~d}$ & $1.51 \mathrm{~b}$ \\
\hline P 0 & 8.95 a & $6.71 \mathrm{~b}$ & $7.88 \mathrm{a}$ & $7.27 \mathrm{a}$ & $0.64 \mathrm{~b}$ & $0.91 \mathrm{~b}$ & $1.52 \mathrm{a}$ \\
\hline Ir 30 days $P 10$ & $8.70 \mathrm{~b}$ & $6.59 \mathrm{c}$ & $7.61 \mathrm{~b}$ & $7.28 \mathrm{a}$ & $0.60 \mathrm{c}$ & $0.90 \mathrm{c}$ & $1.50 \mathrm{~b}$ \\
\hline P 20 & $8.37 \mathrm{c}$ & $6.82 \mathrm{a}$ & $7.35 \mathrm{c}$ & $7.38 \mathrm{a}$ & $0.68 \mathrm{a}$ & $0.92 \mathrm{a}$ & $1.52 \mathrm{a}$ \\
\hline
\end{tabular}

*In a vertical column means having similar letter(s) do not differ significantly according to Duncan's Multiple Range Test at 0.05 level of significance.

** Ir = foliar iron spray, $\mathbf{P}=$ Paclobutrazol $\left(\mathrm{mg}^{-\mathrm{L}^{-1}}\right)$.

The interaction treatment between foliar iron every 30 days and 20 mg. $\mathrm{L}^{-1}$ drench application paclobutrazol gave the highest flower weight and flowering period $(6.82 \mathrm{~g}$, 7.38 days) and gave also the largest amount of essential oil and refractive index (0.68 $\left.\mu \mathrm{g} . \mathrm{g}^{-1}, 1.51\right)$.

Table (2) shows that foliar iron spray of non-grafted gardenia caused a significant reduction response on flower quality characters. Foliar iron spray treatment every 15 days compared with every 30 days gave flower weight, diameter and flowering period (3.21, $1.88 \mathrm{~g}),(3.20,1.96 \mathrm{~cm})$ and (4.11, 2.55 days) respectively. Treatment with 10 mg. $\mathrm{L}^{-1}$ paclobutrazol gave the highest number of flowers (0.88 flower/plant) and the highest flower weight and diameter flower $(3.07 \mathrm{~g}, 3.15 \mathrm{~cm})$. The interaction between foliar iron spray every 30 days and the application drench of paclobutrazol $20 \mathrm{mg} . \mathrm{L}^{-1}$ gave the highest flower weight and flowering period (3.71 g, 5.00 days), while the highest flower diameter $(3.63 \mathrm{~cm})$ was obtained by the interaction between foliar iron spray every 30 days and 10 mg. $\mathrm{L}^{-1}$ drench application of paclobutrazol.
From results obtained here, it can be shown that the number of flowers in grafted gardenia was bigger than that in non-grafted gardenia as well as flower quality specifications, which can attributed to the role of the rootstock (Khosh-Khui and Zargarian, 2010). As it can be seen from the results, there is a positive role of iron in improving the quality specifications of the flowers in grafted and non-grafted gardenia. These of flower weight, diameter and flowering period agreed with those obtained by Abo-Komra and Abbass (2010). They explained the iron's role in the photosynthesis process and the building of proteins. Thus iron improved vegetative plant growth and lead to increasing the efficiency of photosynthesis which improved the quality characteristics of the bloom (Kashif et al., 2014). The iron has a positive role in increasing amount of essential oil and its density and refractive index as stated by Glyn (2000) who sprayed Artimesia annua L. with micronutrients to increase the amount of essential oil.

As noted in this study the low number of flowers had fallen by paclobutrazol. As for the qualitative characteristics of the flowers 
Table 2. Effect of foliar iron spray and paclobutrazole on flower quality characters of nongrafted cape jasmine Gardenia jasminoides Ellis.

\begin{tabular}{|c|c|c|c|c|c|}
\hline \multicolumn{2}{|c|}{ Treatments** } & Number of flowers & $\begin{array}{l}\text { Flower weight } \\
\text { (g) }\end{array}$ & $\begin{array}{l}\text { Flower diameter } \\
(\mathrm{cm})\end{array}$ & $\begin{array}{l}\text { Flowering period } \\
\text { (days) }\end{array}$ \\
\hline \multicolumn{2}{|c|}{ Non foliar spray } & $0.66 b^{*}$ & $2.22 \mathrm{ab}$ & $2.18 \mathrm{ab}$ & $2.66 \mathrm{~b}$ \\
\hline \multicolumn{2}{|c|}{ Ir 15 days } & $0.61 \mathrm{~b}$ & $1.88 \mathrm{~b}$ & $1.96 \mathrm{~b}$ & $2.55 \mathrm{~b}$ \\
\hline \multicolumn{2}{|l|}{ Ir 30 days } & $0.88 \mathrm{a}$ & $3.21 \mathrm{a}$ & $3.20 \mathrm{a}$ & $4.11 \mathrm{a}$ \\
\hline \multicolumn{2}{|l|}{ P 0} & $0.66 \mathrm{~b}$ & $2.24 \mathrm{ab}$ & $2.55 \mathrm{ab}$ & $2.88 \mathrm{a}$ \\
\hline \multicolumn{2}{|l|}{ P 10} & $0.88 \mathrm{a}$ & $3.07 \mathrm{a}$ & $3.15 \mathrm{a}$ & $3.77 \mathrm{a}$ \\
\hline \multicolumn{2}{|l|}{ P 20} & $0.61 \mathrm{~b}$ & $1.99 \mathrm{~b}$ & $1.93 \mathrm{~b}$ & $2.66 \mathrm{a}$ \\
\hline \multirow{3}{*}{ Non foliar } & P 0 & $1.00 \mathrm{a}$ & $3.28 \mathrm{a}$ & $3.11 \mathrm{ab}$ & $4.00 \mathrm{ab}$ \\
\hline & P 10 & $0.66 \mathrm{~b}$ & $2.24 \mathrm{a}$ & $2.28 \mathrm{ab}$ & $2.66 \mathrm{abc}$ \\
\hline & P 20 & $0.33 \mathrm{~d}$ & $1.13 \mathrm{~b}$ & $1.15 \mathrm{~b}$ & 1.33 c \\
\hline \multirow{4}{*}{ Ir 15 days } & P 0 & $0.33 \mathrm{~d}$ & $1.10 \mathrm{~b}$ & $1.16 \mathrm{~b}$ & 1.66 bc \\
\hline & P 10 & $1.00 \mathrm{a}$ & 3.39 а & $3.54 \mathrm{a}$ & 4.33 a \\
\hline & P 20 & $0.50 \mathrm{c}$ & $1.14 \mathrm{~b}$ & $1.17 \mathrm{~b}$ & 1.66 bc \\
\hline & P 0 & $0.66 \mathrm{~b}$ & $2.36 \mathrm{ab}$ & $2.49 a b$ & $3.00 \mathrm{abc}$ \\
\hline \multirow[t]{2}{*}{ Ir 30 days } & P 10 & $1.00 \mathrm{a}$ & 3.58 a & 3.63 a & $4.33 \mathrm{a}$ \\
\hline & P 20 & $1.00 \mathrm{a}$ & $3.71 \mathrm{a}$ & $3.48 \mathrm{a}$ & $5.00 \mathrm{a}$ \\
\hline
\end{tabular}

*In a vertical column means having similar letter(s) do not differ significantly according to Duncan's Multiple Range Test at 0.05 level of significance.

** Ir = foliar iron spray, $\mathbf{P}=$ Paclobutrazol $\left(\mathrm{mg}^{-\mathrm{L}^{-1}}\right)$.

improved by paclobutrazol as it has led to increase weight, diameter and flowering period. This result is similar with results elsewhere (Singh and Bist, 2003). Perhaps the reason for increasing flower weight, diameter and flowering period could be explained by the role of paclobutrazol in increasing the chlorophyll and carbohydrates and work to reduce plant height, which means optimum utilization of carbohydrates manufacturers as well as increased the plant nutrient uptake and a positive reflected turn in flower quality (Grossman, 1990). As for essential oil, it is noticed paclobutrazol role in increasing the quantity and density of the essential oil of grafted gardenia and perhaps the reason is due to the improvement of the flower quality characteristics especially the weight. This result agrees with Said-Al Ahl and Mahmoud (2010) who found that the flower weight increase led to greater content of essential oil.

\section{REFERENCES}

Abo-Komra, H.M. and Abbass, J.A. (2010). Effect of different levels of chelated iron on growth, flowering, quantity and quality of aromatic oil of gardenia plant Gardenia jasminoides Ellis. Jordan
Journal of Agricultural Sciences, 6(4): 630-639.

Al-Atrakchii, A.O. and Saleh, G.Y.Q. (2008). Propagation of gardenia rootstock Gardenia thunbergia L.F. by stem cutting. Mesopotamia J. of Agric., 36(4):9-17.

Grossmann, K. (1990). Plant growth retardants as tools in physiological research. Physiol. Plant, 78(4):640-648.

Glyn, M.F. (2002). Mineral nutrition, production and artemisin content in Arttemisia annual. ActaHort, 426:573578.

Kamoutsis, A.P. and Sereli, A.G. (1999). Paclobutrazol affects growth and flower bud production in Gardenia under different light regimes. HortScience, 34(4):674-675.

Kashif, M.; Rizwan, K.; Khan, M.A. and Younis, A. (2014). Efficacy of macro and micro-nutrients as foliar application on growth and yield of Dahlia hybrida L. (Fresco). International Journal of Chemical and Biochemical Sciences, 5:610. 
Khosh-Khui, M. and Zargarian, M. (2010). Effects of four rootstocks on growth and development of three rose section cultivars. ActaHort, 870:207-212

Koenig, R. and Juhns, M. (2010). Control of iron chlorosis in ornamental and crop plant. Publication AG-SO-01, Utah State University Cooperative Extension.

Pensuk, W.; Padomanonda T. and Pichaensoonthon, C. (2007). Comparison of the chemical constituents in Michelia alba flower oil extracted by stem distillation, hexane extraction and effleurage method. J. Thai Traditional and Alternative Medicine, 5(1):30-39.

PGRSA (2007). Plant Growth Regulation Handbook of the Plant Growth Regulation Society of America. $4^{\text {th }}$
Edition. The Plant Growth Regulation Society of America., Athens.

Said-Al-Ahl, H.A.H. and Mahmoud, A. (2010). Effect of boron and iron foliar application on growth and essential oil of sweet basil Ocimum bacilicum L. under salt stress. Ozean J. Applied Sci., 3(1):97-111.

Singh, A.K. and Bist, L.D. (2003). Effect of paclobutrazol on growth and flowering in rose cv. Gruss-an-Teplitz. Indian J. Hort, 60:181-191.

Tisdale, S.L.; Nelson, W.L.; Beaton, J.D. and Havline, J.L. (1997). Soil Fertility and Fertilizer. Prentice-Hall of India. New Delhi.

\section{إستجابة صفات جودة أزهار الجاردينيا Gardenia jasminoides Ellis المطعومة وغير المطعومة لمعاملات الرش الوردي الورقي بالحديد والباكلوبترازول

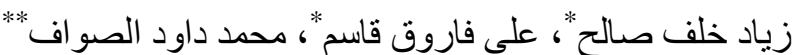

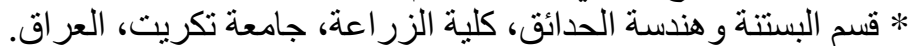

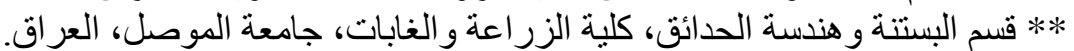

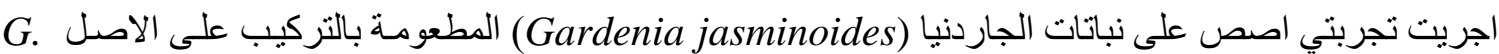

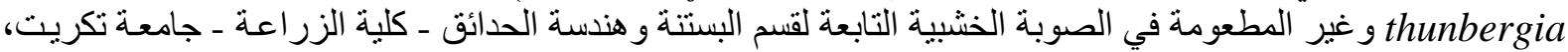

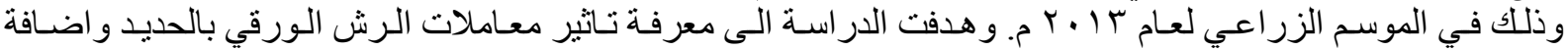

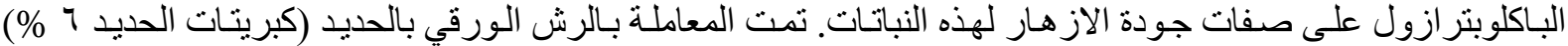

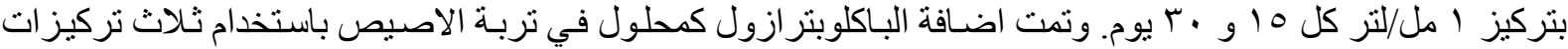

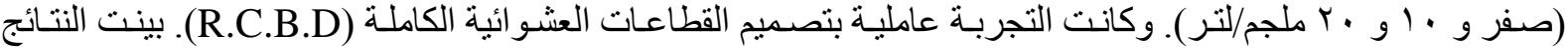

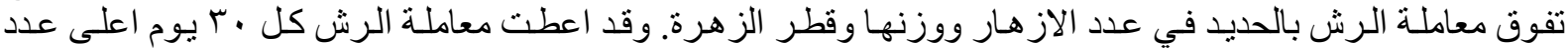

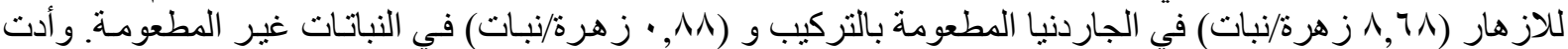

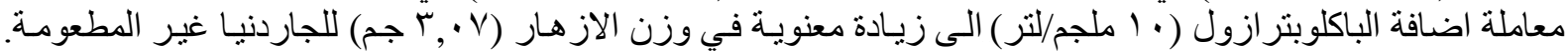

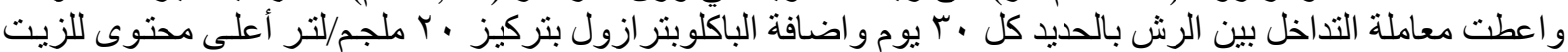
العطري (1^آ, · مايكروجر ام/جم). 


